up I saw that it was being made by a small lizard, apparently in a state of great terror at a snake which was uncoiling itself from the rafters close to it. I cannot say what the species of the lizard was, but it was one of those so abundant on the walls of Indian houses ; it was one of two that appeared every evening, when the lamp was brought out into the verandah, and feasted on the moths attracted by the light.

20, Duke Street, Edinburgh, May 5

\section{THE ECLIPSE EXPEDITION}

THE Daily News of Tuesday publishes the following communication from its special correspondent with the English Eclipse Expedition :-

\section{On the Nile, between Siout and Sohag, May 6}

The astronomers have now nearly reached their destination if all goes well, but it is by no means certain that everything will, for the Nile has never been known to be so low, and we have already been aground many times. To-morrow morning will see them and their instruments landed after their last water journey. The arrangements made by the Egyptian Government and by His Highness the Khedive himself, who takes the liveliest personal interest in the work, have been simply perfect. Everything seems to have been foreseen, every possible cause of delay obviated, and everything that could conduce in any way either to the comfort of the observers or the success of the observations provided. One officer of the Egyptian Government or another has been in constant attendance upon the expedition since they landed at Suez, and any indication of a desire that a certain course of action should be taken has been at once attended to. There is no shutting one's eyes to the fact, that there are many men occupying high positions in this wonderful country, through which we are now journeying, who take the keenest interest in scientific progress, and who are more than anxious, that Egypt should take her place among the more highly civilised nations, among whom science is cultivated to a greater or less extent; and there can be little doubt, that the efforts now being made to educate the people will in time bear more fruit of this soil. It is quite apropos to this train of thought to mention, that the fact that the admirably equipped ubservatory of Cairo will count for very little among the proposed observations is keenly felt. It must not, however, be imagined that because the metropolitan observatory counts for so little, Egypt possesses no astronomers. mentioned in a former letter that it was hoped that Ismatt Effendi, a member of the Khedive's household, might be attached to the expedition. When the expedition reached Suez and the Kaisar-i-Hind steamed into the harbour, it was easy to see that something unusual was going on there. The Khedive had not only sent Ismatt Effendi to receive the expedition, but had sent orders to the Governor of Suez to welcome it in his name. Nor was this all. A special train had been provided for the instruments and observers, and every precaution taken for safe handling and safe custody of the former. In the morning the Governor of Suez speeded the parting guests, who were accompanied by $M$. Ismatt, and this gentleman soon showed how much he had profited by the long training be has received in the observatories of Paris and Washington, and it was soon acknowledged that in him the expedition not only found a most useful and agreeable companion, but a collaborator of the highest value.

Un arrival at Cairo the party found General Stone, chief of the staff, accompanied by Moktah Bey, on the platform to welcome them. Of the former, it may be said that his influence for good on the higher education in Egypt and on the officers who have served under him is freely acknowledged. He has lost none of the enthusiastic love of truth for its own sake, and of science for the sake of the world, which characterises so many of the best of his countrymen; and many of his remarks touching his conception of the duty incumbent on the Government of Egypt, in aiding a work of international aim, strongly reminded me of General Sheridan's thoughts and words when he received at Washington one of the English observers of the eclipse of 1878. Moktah Bey, who has been detailed to accompany the expedition, is an officer who has greatly distinguished himself by his travels in the Soudan. He is not only an admirable administrator, but a capital linguist, while his love 'f work in the Soudan and in Upper Egypt in triangulation, determining latitudes and longitudes, and establishing, or endeavouring to establish, meteorological observatories, nileometers, and the like, render him also a valuable scientific ally.

General Stone, on the arrival of the instruments at Cairo, cut a Gordian knot by at once ordering the car containing them to be ferried across the Nile. There is no railway bridge over the Nile at Cairo, so that considerable time was saved and risk avoided by this measure. In fact it may be said that not only were the cases containing the instruments untouched from Suez to Siout, but that they were actually sealed up all this time. There was not much time to give to the strange sights and old memories of Cairo; even the Pyramids have remained unvisited so far, for after resting one night and spending part of the next day in official visits, the party was off again yesterday and trevelled during the night down to Siout, the most southerly railway station in Egypt, and about 70 miles north of the point where the eclipse line crosses the Nile. At Siout, whither extra camels and porters had been summoned by telegraph, the sight at sunrise this morning was strange beyond all description, or at all events beyond the descriptive powers of your present correspondent. The telescopes to be used on the present occasion are of very great weight, and although they have been divided into as many separate pieces as possible, some of the cases are still very heavy, taxing the powers both of men and camels to the utmost. The camels, which were made to kneel down so soon as the cases had been got out of the railway car, groaned as they rose with such an unaccustomed weight; and giant Arabs, goodnatured sons of Hercules, did the rest at the boat side. But here again a special arrangement was necessary. The Nile is so low and the steamer was already so crowded that the instruments were placed in a special boat taken in tow by the steamer. Events have shown that this precaution was by no means an improper one, for during the last hour and a half we have been firmly aground, and it does not seem as if all the shouting of the motley crew, or any manœuvring of the engine is going to get us off again. While these attempts, which seem born of confusion, are wearing themselves out, it will be as well to say a word about the final arrangements, so far as they are known to us, before we actually arrive at the station.

There are three expeditions in Egypt for observing the eclipse-a French, an English, and an Italian one. As there is so little choice of station, his Highness the Khedive has sent forward a steamer to Sohag, the point at which the eclipse track crosses the Nile, and has invited the various expeditions to use this as a point d'appui and floating hotel wherever their actual place of observation may be. Prof. Tacchini forms part of the Italian party, and MM. Thollon and Trépied of the French one. The latter have gone on ahead, and it is thought that their instruments are already up and adjusted, while the Italian party follows us on Monday. It is believed that the work of both of these parties will be chiefly spectroscopic. As the exposure of Capt. Abney's plates forms an important part of the English plans, it is intended to take special precaution for securing the photographic rooms and tent from dirt. With the same object in view covers have been prepared for the telescopes, which closely fit them and can be kept, it is fondly hoped, sand-tight. This brings me to say a word about the khamseen. The season this year 
in Egypt has been extraordinary. There has been much rain and very little khamseen, and now there is a brisk north wind blowing, which generally follows the dust wind. Hence many weather-wise people say that the khamseen is over; if so, of course, all the better. On the other hand, to-night from our sandbank we have witnessed a sunset rendered transcendentally beautiful by clouds over fully one-half of the sky. It is possible therefore that if the present weather continues, the sky will not be quite so free from vapour as it is generally in Upper Egypt. To avoid the khamseen, General Stone, who has had the region reconnoitred, has suggested to the English party to occupy an eminence to the northwest of Akmin, a village a little higher up the river than Sohag.

\section{Near Sohag, Sunday}

I had got so far at I I last night, when the time came for closing the mail bag, although we were fast aground, and apparently with less chance than ever of getting off. There were two mail bags, however, made up after all, for the service is so interfered with higher up the Nile that I am still in time on Sunday evening to send a letter which ought to catch the next Brindisi mail, though whether it does or nor is very doubtful, for we have been aground again twice to-day.

So, as we have at last arrived at our station, I will endeavour to give an idea of the proposed arrangements. In the first place, we have found the steamer on which the various parties are to live as the guests of the Khedive moored close to the shore, at a point where it trends north and south, or very nearly so, about half a mile below Sohag. This position, which has been selected by the French party - the first to arrive-is a very admirable one for two reasons. First, the constant wind during the last week has been from the north, and by keeping a staff of people watering the foreshore of the Nile, all dust is obviated. To the north of the place of observation trees, and what looks like grass from a distance, grow close to the margin of the river; so that the dust can only be of nearly local origin; while a long stretch of sandbank to the north, running east and west, is far enough away to deposit its sand in the Nile before it can reach us.

Secondly, the khamseen, if khamseen there is to be, will have to travel a mile and a half along the Nile before it can enter the observatories; and it is thought this amount of water surface will have an important effect in reducing the amount of sand in the air, even in its case also. Nous verrons. These considerations have induced the Inglish party to take up ground close to the boat and their French confrères. The hills which look so tempting in the mass are simply impossible as places of observation. With the means at command here it would take a week to get the instruments up, much more in position; while at Akmim, which is only two or three miles away, there does not seem to be any spot more favourable, taking everything into consideration, than the one here.

At five o'clock to-morrow, then, the work will begin, and the next week will be a busy one, for in spite of the fresh breeze and the clouds-for there are very distinct clouds to-day--work on the sand becomes very oppressive in the middle of the day, and there are heavy weights to move, which the observers must move themselves. The scene from the ship is already interesting. To the north two tents and various shelters, to the south one tent. These will increase to six to-morrow. Here and there groups, looking down the bank, stealthily from between the trees. There is a pretty thick grove of acacia trees, which shelter us somewhat from the rays of the setting sun, still fierce in this latitude. Here and there, skirting the grove, a sentinel with fixed bayonet keeping guard. At the extreme soutb, tents for the military, and a long line of piled arms.

Across the water the scene is novel and beautiful in the extreme. The main Nile, in which the bat is anchored, is here about half a mile wide, but there is an island about two miles long, and a wide stretch of water beyond that. This island forms, with the river, the foreground of the landscape. With an opera-glass we can see the Fellaheen cultivating the ground almost to the water's edge in places, and looking after their crops of maize or their flocks of goats. Here comes a veiled Rachel to the sacred river to fetch water for a house in an indistinct flat-topped village, sheltered in a large group of beautiful palm trees. The arm of the river beyond the island we cannot see, but a background is not lacking. A long line of mountains, we may almost call them, full of geological tracery, are now, as I write, almost blood-red in the light of the setting sun, and are surmounted by that grey purple one always sees to such advantage in Eastern lands-both grey and purple haze in a few hours to give way to the silver dawning of the moon, now terribly dwindling in her visible surface, and reminding the astronomers of the coming seventy seconds in a most forcible manner.

The proceedings at the end of the first day on which the English and French parties found themselies together as guests of the Egyptian Government naturally included some toasts - that of his Highness the Khedive, proposed by M. Trépied, and that of the English and French nations, proposed by Moktah Bey, and responded to by Mr. Norman Lockyer. The arrangements on board are as perfect as those made at the various stations on shore, and one's national pride is a little touched at the idea of what the Government reception would be of a party of Egyptian astronomers coming to England to observe an eclipze of the sun.

\section{ANEMOMETRICAL OBSERVATIONS ON BOARD SHIP}

I $\mathrm{T}$ is known that the determination of the velocity of the wind in the ocean has always been one of the desiderata of meteorological observations. Maury devoted much attention to this subject, and to determine, at least approximately, the velocity of trade-winds, he was compelled to work on a very unsafe basis-the velocity of ships during different parts of the year-and to put aside all observations made in accordance with the scale of Beaufort as unreliable. But it is obvious that the velocity of a ship depends on so many circumstances quite independent of the wind itself (such as the shape of the ship, the surface of its sails, the disposal of the cargo, and so on), that its velocity is kut a very imperfect means of measuring the velocity of wind. Besides, the relation which exists between the force of the wind and the velocity of a ship, under different angles between the direction of both, is a new source of error, as this relation has not yet been established with accuracy, and can be established only by means of anemometric measurements. The necessity of trustworthy measurements of the velocity of wind at sea was so well understood in England that the Royal Society and the British Association established in 1859 two anemometers-one on the Bermuda Islands, and the other at Halifax. But it is known that the force of the wind is usually lessened on continents and islands.

Therefore it was absolutely necessary to make anemometrical observations on board ships, and a few attempts had already been made in this direction. Prof. Piazzi Smith invented an anemometer which might be established on board a ship, and which merited the bighest eulogy from Maury, but Lieut. Domojirov does not know if any observations were made with it. Emil Bessel, during the Arctic expedition of the Polaris, made a series of observations with an anemometer on board his ship, but he does not explain, neither the methods of observation, nor the corrections he applied to his measurements. In

${ }^{1}$ A. Domojirov, in the Izvestia of the Russian Geographical Society, vol. $x$ viii. 1882 , fasc. $x$. 